\title{
DIMPLES IN APPLES FROM OVIPOSITION OF LYGUS PRATENSIS L.
}

\section{By Estes P. Tartor, Mountain Grove, Missouri}

To one conducting experiments against insect pests infesting fruits it is especially important that the cause of all external blemishes upon the fruits be known. Failure to recognize the cause of such injuries has often been responsible for misleading and incorrect conclusions regarding the effectiveness of insecticidal sprays. Mistaken. identifieation of insect work is often brought about by superficial examination of fruit at picking. At this time the growth of the fruit has often so completely altered the appearance of the injury that its true cause is never suspected.

Careful and almost continuous observations in an apple orchard this season from the time of the formation of the fruit to harvest resulted in the discovery that an injury of doubtful nature but resembling and formerly classed as that caused by the plum or the apple curculio was, instead, the result of egg punctures made in the very early development of the apple by the common tarnished plantbug (Lygus pratensis L.). On account of their direct bear ng upon the examinations of apples by those conducting spraying; experiments in the control of curculio upon apple, the results of these observations are herein reported. The observations also add new information upon the egg-laying habits of the tarnished plant-bug, one of the oldest recorded insects in North America.

Late in March at Mountain Grove, Missouri, my attention was called to the great abundance of the tarnished plant-bugs about the buds and newly opened blossoms of early blooming varieties of peach. They were noted in great numbers about the blossoms of peaches in the station orchard by the director of the station, while engaged in hand pollinating blossoms. Many blossoms were seen at this time which had evidently been blasted by this insect having piereed the tissue and sucked away the juices of the essential organs of the bloom. A very noticeable percentage of the blossoms were noted at that time darkened and shrunken and falling away, evidently from this cause. At Olden, on March 27, I noticed numbers of the bugs about the buds of peach, plum, apple and pears, and in making jarrings for curculio under peach and plum trees a number of the bugs were collected upon the jarring sheet. On April 10, while examining with an assistant, Mr. C. B. Dull, fruit buds in an apple orchard selected for a spraying experiment with curculio and codling-moth, small dark-colored spots 'were noticed upon the sides of the ovary of the apple bloom. These 
spots were first noticed upon apples of the Blue Pearmain variety, which hat only within the past two or three days completed the shedding of the petals, and upon none of which were the calyces closed. At first the spots were taken as the first evidences of apple scab. A closer inspection suggested the feeding punctures of the plum curculio. Examining the spots under a hand lens I discovered to my surprise that in the center of the discolored area there was a distinct opening in the skin of the apple and that within this opening and just beneath the surface was an oval, elongate, bottle-shaped egg. At first I did not recognize the egrg as any with which I was familiar. The abundance of the tarnished plant bug upon the blossoms of the diff'erent orchard trees mentioned suggested their association with the exors found, which was substantiated a moment later by the capture on these trees of gravid female specimens of Lygus pratensis, from which egogs were dissected. These eggs corresponded perfectly with the ones found deposited within the minute apples. By dissection two females yiclded fourteen well defined eggs each. To further substantiate the observation a large number of the newly formed apples, containingr what appeared to be freshly deposited eggs, were confined in a lreeding cage in the insectary. Hatching began eight days later, yielding the young of this plant-bug. These were kept alive in the cage until they had entered the second or third instar, in which they demonstrated plainly the characteristic markings upon thorax and body, distingmishing this species from related ones. Besides the apples ent open in examination for eggrs and those reserved for breeding cages, a considerable number of small apples were picked at random from two or three Blue Pearmain trees on April 10 and examined in the laboratory with the following results:

Number of apples examined................. 110

Number egrgs found..................... 65

Number feeding punctures.................. 11

Apples bearing eggs.................... 45

In this case it will be seen that about 40 per cent of the apples bore egg punctures of this jnsect. The arerage number of eggs per apple in infested apples was 1.44. One small apple was found containing four punctures with eggs, four contained three eggs each and nine apples bore two eggs apiece. The eggs measured upon an average $.782 \mathrm{~mm}$. in length by $.241 \mathrm{~mm}$. in diameter at their widest point. They were smooth and slightly curved, with the end deepest in the tissue bluntly rounded. The end of the egg nearest the surface was truncate and slightly compressed and bore around the margin a white tubular fringe, finely striated. The color was very pale yellow. 
The eggs were found laid singly in the fruit, though where very small apples contained several the distance between them was often very small. Sometimes two or three would be found arranged in a row, not more than one millimeter apart, but each egg oceupying a separate and distinct incision. The usual rule was that of single and scattering egg punctures. The eggs were placed on end or at right angles with the surface of the apples, snugly fitting into the incisions made for them. These incisions when made in the sides of the ovaries of blossoms which had but recently shed their petals were of depth sufficient to pierce the carpel walls. In one instance an egry was founcl in an incision made within the stem of the miniature apple. Ont of thirty-six egrg incisions counted, fifteen were in the third no arest the tip or calyx end, thirteen were in the middle third, and eight were made in the third nearest the stem. The egrgs are deposited in the apple usually with the outer end just beneath the surface of the skin. Quite often the growth of the tissue of the apple forces the egrgs outward lengthwise and they may often be seen with their whitish truncate tube-like ends extruded into view as much as one third or one half the length of the eggs. It is not altogether unlikely that this may be in some cases due to shallow egg laying by the female. When not extruded in this manner they are difficult to discern, as the heavy pubescence over the minute apples conceals them. Freshly laid eggrs are more difficult to discern since the tissue surrounding has not become discolored.

Eggs are laid sometimes before the petals fall from the blossom and probably some are deposited while still in the bud. No freshly laid eggs were found in any case after the apples were more than one third of an inch in diameter, and usually not later than the time of the closing of the calyx. The past spring the early bldoming varieties suffered more heavily than those opening later. Though exgs were hatching from Blue Pearmain on April 18 the eggs laid in late blooming Ingram were found hatching in the orchard May 1. The adults became more scarce upon fruit trees after the dropping of the petals, although some were seen resting upon the fruit of peaches, wien they measured over an inch in diameter. Although the insect is reported as one with two or three generations in Missouri, no egg laying was observed in the apples at any time through the summer.

To determine the effect of the egg-laying upon the development of the fruit a close watch was kept of marked apples known to have had the egg puncture of this insect made upon them. It seemed apparent that the injury probably caused the dropping of some of the small apples soon after setting. By far the larger percentage of affected 
apples, however, hacl their growth arrested at the point of egg layjug, which with the growing of surrounding tissue brought about the formation of small, fumnel-shaped pits upon the surface about each "gge incision. Cpon the 14th of May, while the Ingram apples were still small and covered with a fuzzy pubescence, 31 fruits which bore 36 unmistakable exgr pits from the tarnished plant-bug were carefully marked upon the trees. These were observed from time to time and development of the egg-pits noted up to the time of the full maturity of the fruit, which was harvested October 6. Although, as stuted, the rariety did not seem so heavily infested as some of the rarlier blooming ones, a count of 2,189 apples picked from nine small trees showed about 3 per cent with well defined cavitios upon their surface due to this cause. Some apples bore as many as five eggpits cach. Measurements of twenty-one cavities upon apples varying from two to three inches in diameter gave an average distance across the top of the depression of .49 inch, with a variation of from .30 to .75 ineh. From the surface the sides of the eavity sloped gradually to the botfom, forming an inverted cone-shaped depression with an average depth of .17 inch and a variation of from .08 to .35 inch. Isading inwarl into the apple from the bottom of the cavity is a greenish, pithy tissue, which extends in a straight line toward the core, sometines terminating within and sometimes just outside the carpel walls. If the injury has been ncar the stem or calyx end of the apple the threadlike canal may reach the core above or below the poles of the curpels. This hardened tisstue is sometimes of a tubular form, having an average diameter of about $.02 \mathrm{inch}$. It is sometimes open but is for the most part filled with a loose, brown, cellular tissue. It is the outgrowth of the original eavity in which the eggs were laid and in one instance what appeared to be an empty egg-shell was dissected from the base of one of these egg-pits in a matured apple on October 31, fully six months from the date of oviposition, the observation affording still further and convincing proof of the cause of the injuries noted. The ego-pits must be considered of some economic importance to the fruit grower but they do not seriously affect the kreping quality of the fruit and, except in cases which canse scrious distortion of the fruit, does not lower its grade.

That injuries in apples due to the oviposition of the tarnished plantbug may be expected in any portion of the United States where this fruit is grown is probable, since this insect is widely distributed. Such an omnivorous feeder may be expected to be present and ready for oviposition in apples in the spring in almost any quarter. The typical exw-pits of this insect were noted the past season, more or less, 
in all fruit districts visited in Missouri. It is known to ocenr over the United States, from the sea-coast to above timber-line on the highest mountains of the Rockics in Colorado. It langes south jnto Mexico and north far iuto Cauada. It is one of the well known insects of Europe, having first been described by limnaeus in 1767 snd again under another name by Palisot de Beaurois in France from insects collected in Africa and America. It was first brought to the notien of American entomologists by Thomas Say in 1831 and mentioned as an injurious insect by Tarris in $18+1$. It is mentioned as an cconomic pest by Riley, Walsh, LeBaron, Cooke, Glover, Saunders ani Iugorer and has at some time or other been included in the reports of neary every leading entomologist in the country.

So far as the writer is aware this record is the first of oriposition of the insect in apples, or in fact in any fruit. Professor Woolworth states that the egg of this insect was not known at all until $188+$ when Doctor Forbes, after a protracted search. succeded in findius a single specimen anong the hairs of the petiole of a dead strawhery leat, and Professor Slingerland is reported to have found their exgs in blighted peach twigs in New York.

It was no small satisfaction to the writer to be alle to accurately identify these egg-pits this fall upon apples in experimental hlocks, very successfully treated for the control of curculio and codling-moth. Without this knowledge I should have been led to classify the injuries as the very early food punctures of the apple cureulio (Anthonomus: quadrigibbus Say), or even the early food pumctures of the plum curculio (Conotrachelus nenuphar Hbst.). It seems poss ble that failures, or at least only partial successful results, which hirve ben reported in the control of curculio upon apples with arsenical sprays, has been due to this mistaken identity of injuries.

Remedies or preventive measures will not be discussed in this article, but it has been observed by the writer that orchards where clean cultivation is practised and where a minimum number of aclults are permitted to hiberuate through the winter suffer least from spring oviposition in the fruit.

The plotograplis reproduced herewith show the exg-pits from the tarnished plant-bug in Ingram apples in their various sages of growth. Fig 1, Plate 10, in which the size of the apples is reduced about one half, shows the depressions upon apples when very suall, still coated with pubescence and less than a month after the batching of the plant-bug eggs. Fig. 2, Plate 10, shows apples of ahout one third size, about two months from egg hatching. These woll illustrate the depressions which may be appropriately spoken of as "dim- 
Plate 10
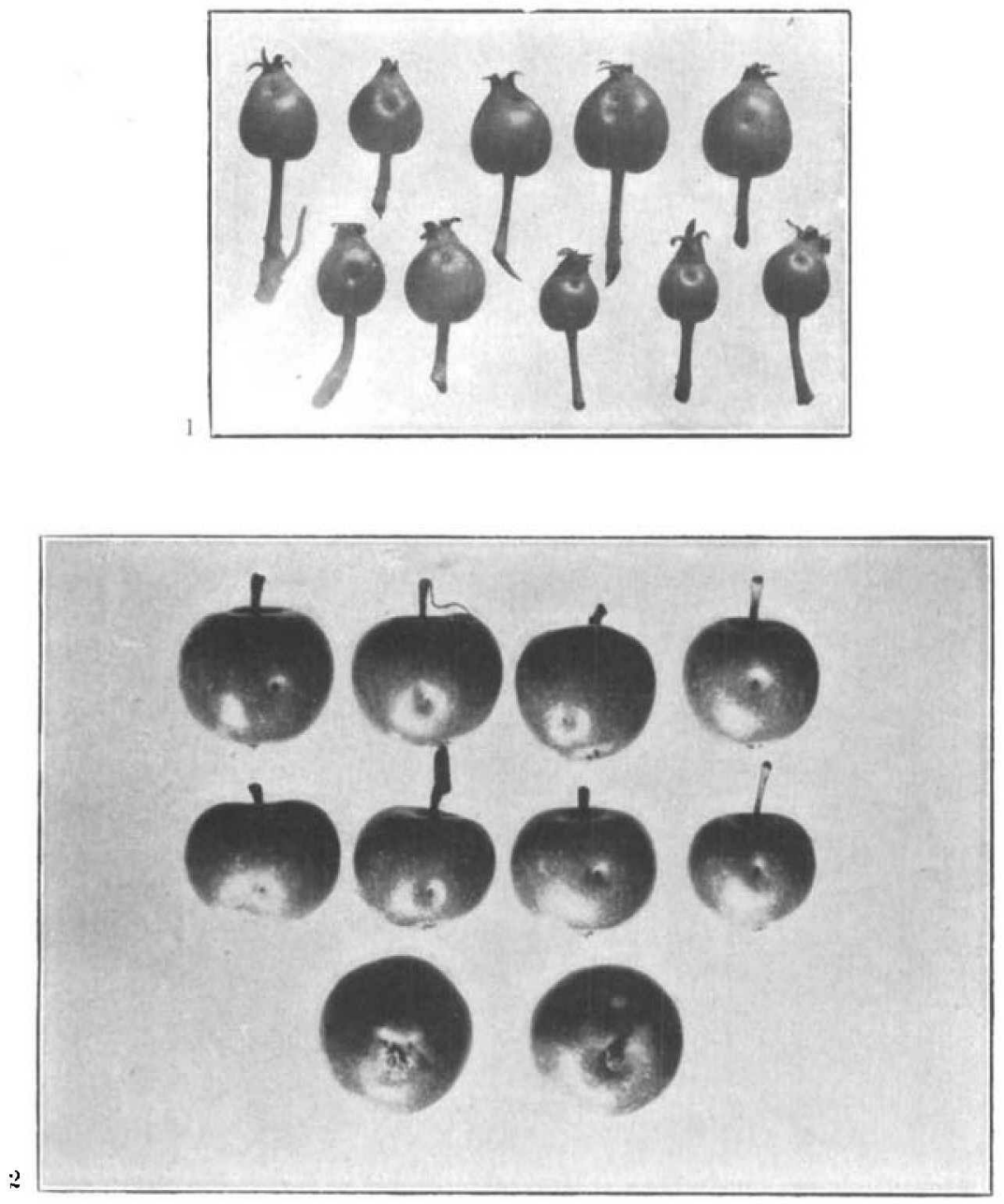

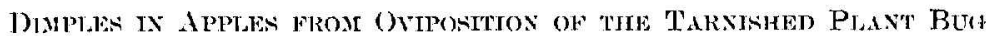


Plate 11
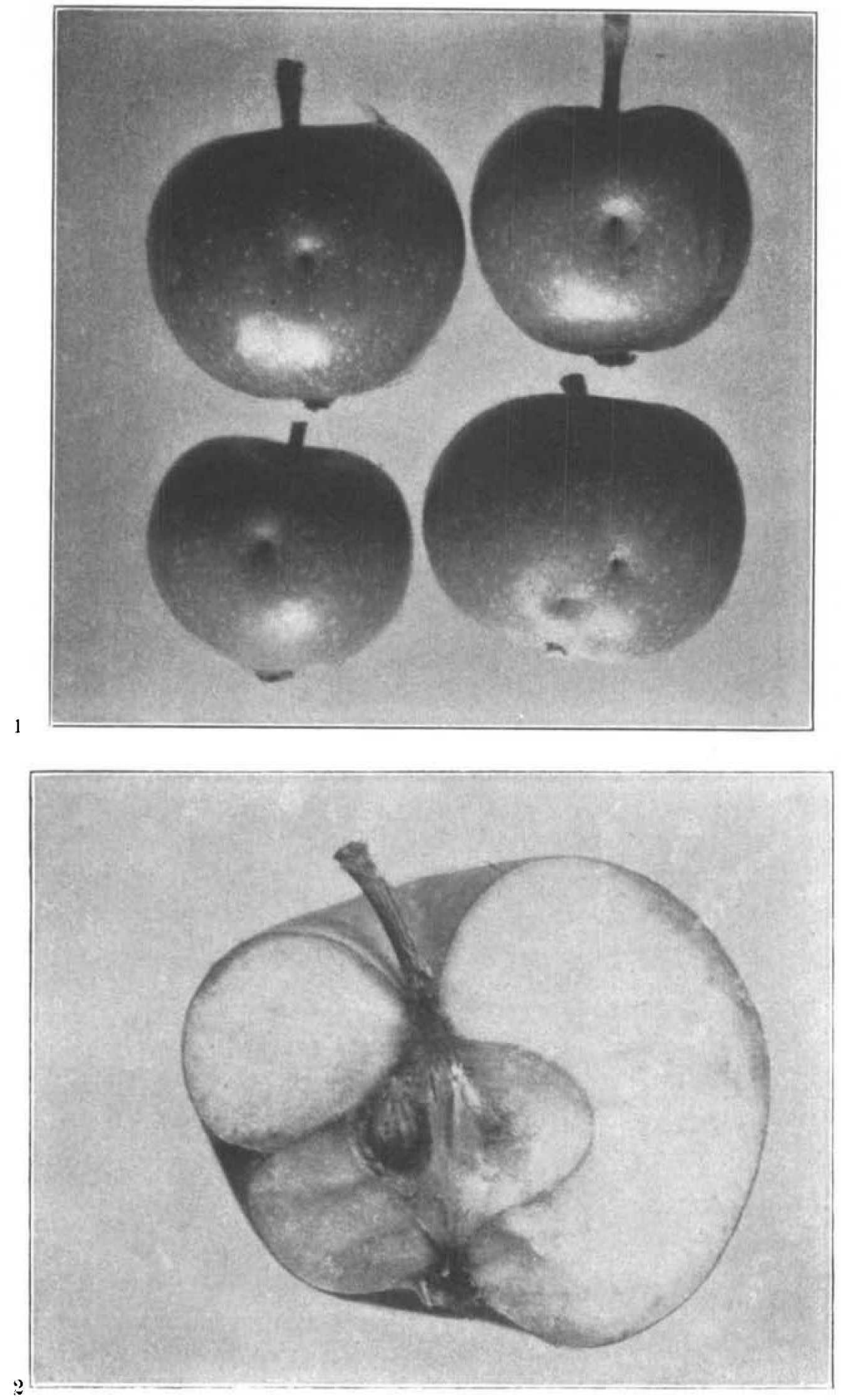

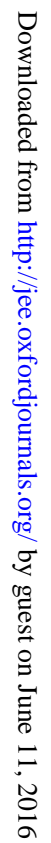

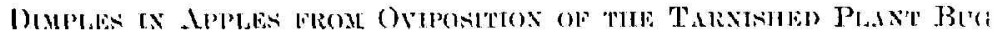


ples." Fig. 1, Plate 11, was taken about two months from the hatchingr of the plant-buer egg and shows apples and dimples about natural size. Gne of the apples exhibits two dimples on the surface shown. In Fig. 2, Plate 11, is shown an Ingram apple about natural size in longitudinal section. with the depression and pithy tube, the outgrowth of the egg incision, extending nearly to the core. The axis of the apple is twisted, resembling distortions from other insect injuries. This photograph was taken at harvest time, about five months from the hatehing of the egg of the tarnished plant-bug.

\title{
NOTES ON THE GRASS MITE, PEDICULOPSIS GRAMI- NUM REUTER
}

\author{
H. E. Hongriss, Geneva, N. Y.
}

This speecies belongs to the l'arsonemidie, which is a small family of the order Acarina. The mite was first described in 1900 by Dr. Enzio Reuter ${ }^{1}$ from specimens taken from grass in Finland, and was placed by him in the genus l'diculoides under the specific name graminum. Doutor Reuter afterwards recognized characters of generie significanere in this species and thereupon erected the genus Pcdiculopsis, naming iraminum as the type."

The importance of the species was first indicated hy Doctor Reuter

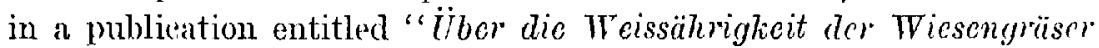
in Finland." In Bank's list of the Acarina of the Cnited States no mention is made of this mite, and its identity in this country appears not to have been determined until the present time.

In 1905 Dr. R. II. Wolcot mentioned the appearance of a mite in carnation buds. ${ }^{2}$ During the following year the presence of a mite was noted in carnation buds grown on Long Island, and in 1907 it was identified as l'ediculoides gramimum Reuter. In 1908 IIeald and Wolcott published an account of the species under the name Pediculoides dianthophilus. ${ }^{5}$

Carnation buds infested with the mite were received from P'rofessor: Heald, for the purpose of identifying the Nebraska species, which proved to be the same as the one found in New York. That there might be no doubt as to its identity, specimens were sent to Doctor

${ }^{1}$ Acta Societatis pro Fauna et Flora Fennica, 19: N:0 1. 1900.

${ }^{2}$ Festschrift für Palmén, N:0 7, p. 3, footnote 2. Helsingfor's. 1907.

sproc. U. S. Nit. Mus., 32: 615.

'Science, N. S., 21:389. 1905.

${ }^{5} \mathrm{Neb}$. Sta. Bul. 103. 1908. 